\title{
Contraception choices for transgender males
}

We wish to share with journal readers a clinical case that challenged us clinically and highlighted a number of learning points for our community sexual and reproductive healthcare (cSRH) service.

A transgender male attended our integrated sexual health clinic with a presentation of blisters. He had had unprotected vaginal sexual intercourse 5 days previously, and had been paid for this episode of sex. He was in a long-term relationship with his female partner, and was considering going into casual sex work (CSW). Currently he was a full-time carer for his partner, while also trying to hold down a parttime cleaning job. His transgender friends had informed him that there was a market for transgender males in the CSW industry, and he thought that this might be an opportunity for him to support himself and his partner financially. He had undergone a full sexual health screen that included herpes simplex virus testing and bloodborne virus screening. He was treated empirically for herpes and commenced on a rapid hepatitis $B$ vaccination programme. 
On discussing contraceptive options he thought that he did not require contraception as he had been on testosterone for a number of years and was amenorrhoeic. He had discussed this with his transgender friends and they had also thought that contraception was not required. We gave him a Family Planning Association (FPA) Choices leaflet and arranged to see him for his second hepatitis B injection the following week; in the interim we sought advice regarding trans-specific contraception issues.

We discussed his case within our team that included the specialist consultant from our local cSRH service. We reviewed current evidence via the Faculty of Sexual \& Reproductive Health's Clinical Effectiveness Unit Members' Enquiry database. Current evidence demonstrates that fertility can be reduced by testosterone; however, it is not possible to state categorically that pregnancy cannot occur, and on the basis of this evidence we advised that he needed to consider contraception. ${ }^{1}$

Progestogen-only contraceptive methods would not interfere with the process of masculinisation. Levonorgestrel or norethisterone are the most androgenic progestogens, but as a progestogen-only pill (POP) they only have a 3-hour window, which may be difficult to comply with in order to maintain contraceptive efficacy. The desogestrel POP is a good oral option because of the longer administration window. The other important consideration in this particular situation is whether the individual is still having periods and the possibility of irregular bleeding with an oral method, which may be unacceptable to a trans male. An intrauterine system or an injectable progestogen could be considered, either of which is more likely to achieve amenorrhoea.

When our client attended his next appointment we discussed the currently available evidence that we had reviewed and he decided on Depo-Provera ${ }^{\circledR}$ injection. Our client commented that the leaflets he'd been given were not transgender-friendly.

This clinical situation highlighted a number of learning points for our service. These included the lack of currently available evidence on pregnancy risk and fertility in a transitioning trans male; the potential misconceptions regarding fertility and pregnancy risk in the trans community; and the lack of trans-client-specific literature about contraception, which is something we are looking to address within our integrated community service.

Patient permission to share this case has been obtained.

\section{Kathy Jones*}

Royal Liverpool University Hospital, Liverpool Centre for Sexual Health, Liverpool, UK; kathy.jones@ rlbuht.nhs.uk

\section{Martyn Wood}

Royal Liverpool University Hospital, Liverpool Centre for Sexual Health, Liverpool, UK; martyn.wood@ nhs.net

\section{Liz Stephens}

Liverpool Community Health, Abacus Sexual Health Service, Liverpool, UK; liz.stephens@liverpoolch. nhs.uk

\section{*Corresponding author}

(C) Faculty of Sexual and Reproductive Healthcare of the Royal College of Obstetricians and Gynaecologists (unless otherwise stated in the text of the article) 2017. All rights reserved. No commercial use is permitted unless otherwise expressly granted.

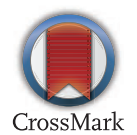

Published Online First 17 June 2017

J Fam Plann Reprod Health Care 2017;43:239-240. doi:10.1136/fprhc-2017-101809

\section{REFERENCE}

1 Faculty of Sexual \& Reproductive Healthcare Clinical Effectiveness Unit. Members' Enquiry response: 3902, 2012. 